\title{
Weather Variability in the Vicinity of Waste Dump-Sites in Benin City
}

\author{
F. Ozabor (Corresponding author) \\ Dept. of Geography and Environmental Management \\ University of Port-Harcourt, P.M.B 5323, Choba, Nigeria \\ Tel: 234-816-931-2952Ｅ-mail: Famphidoz@gmail.com
}

\author{
M. B. T. Kpang \\ Dept. of Geography and Environmental Management \\ University of Port-Harcourt, P.M.B 5323, Choba, Nigeria
}

Received: July 20, 2018 Accepted: August 10, 2018 Published: September 12, 2018

doi:10.5296/emsd.v7i4.13636

URL: https://doi.org/10.5296/emsd.v7i4.13636

\begin{abstract}
This study examines the contribution of dump-sites to weather variability in Benin City. By utilizing the experimental research design, the researcher collected primary data for waste volumes, GHGs, and temperature across the study sites for a period of three months. Analysis of variance (ANOVA) and multiple linear regressions (MLR) were employed for data analysis. Findings revealed that highly populated areas such as, Iguomo (7.7\%), Ekehuan (7.8\%), GRA (6.8\%) and New-Benin (9.2\%) generated the greater proportion of waste in the area. The ANOVA analysis showed that temperature is significantly different as distance increase from dump site at $\mathrm{P}<0.05$ indicating the influence of waste dumps on temperature in the area. Nevertheless, the MLR identified that temperature attained at the various dump sites significantly depended on the GHGs emitted at the sites at $\mathrm{P}<0.05$. The study as a result of findings, advocates waste re-use \& recycle; and establishment of waste treatment plants amongst others in the area.
\end{abstract}

Keywords: Weather, Vicinity, Dump-sites, Variability, Temperature

\section{Introduction}

The simplest definition of waste is "any phenomenon deemed useless by a person, group of persons or a community". The idea of waste in today's world is defined relatively; this is 
because, what is called waste by a group of persons, maybe resource to another (Ozabor \& Obisesan, 2017). Similarly, the ability to manage generated waste is related to the level of technological advancement, level of orientation of the citizenry and preparedness by both the government and citizenry to manage waste (Dienye, 2014). Therefore, the developed countries run parallel to the developing countries when it comes to waste management (Babayemi \& Dauda, 2009; Uwadiegwu \& Chukwu, 2013).

In the developed countries waste is easily recycled and converted to other uses, thereby becoming resources rather than a burden (Ogu, 2000). However in the developing countries waste management is a huge burden, especially in urban centres. It is a common sight to find waste along streets and in residential areas. In some cases attempt is made to create designated waste dumps, however, due to poor dump site management, these waste dumps rapidly become a menace to the environment where it is located. Some of the implication of poorly managed waste dumps include, health (Ozabor \& Obisesan, 2016; Wokekoro \& Inyang, 2007), city's aesthetic depreciation (Atuegbu, 2007; Agbola \& Jinadu, 2006), GHGs emission (Efe et al., 2013).

In Benin City, population was 1.2million in 2006 (NPC, 2006) and with a growth rate of 3.3 the population is projected to reach 1.6 milloin by 2017 . This population have only seven designated waste dumps designed to manage generated wastes in the city. These waste dumps are too few to handle the generated wastes. This assertion quickly manifests in wastes spilling from the intended land holding to other areas not intended to handle the wastes (O'Neill, Landis, Kellar \& Lutz, 2001). As a quick fix approach wastes managers' incinerate accumulated waste openly (when weather conditions are favourable) (Sridhar, 2006), and when weather conditions are not favourable, wastes are left at the dump sites unattended to, thus the organic materials in the wastes hip ferment openly. Incinerated waste materials in the wastes hip and fermented organic materials both emit GHGs. These gases therefore create a greenhouse effect and leading to artificial increase in temperature (Efe, 2002; Aboyade, 2004), in the vicinities of waste dump-site, thus resulting in a heat island effect (Stewart, 2001).

Some studies have inquired about the health effects of waste dumps (Ozabor \& Obaro, 2016; Yusuf \& Oyewunmi, 2008) others have looked at the environmental dangers of poor waste management (Bogner, Ahmed, Diaz., Faaij, Gas, Hashimoto, Mareckova, Pipatti., \& Zhang, 2007; Sánchez-Rodríguez, Seto, Simon, Solecki, Kraas \& Laumann, 2005); while Efe et al., 2013, looked at the GHGs pollution associated with poor waste management in urban centres. This study is spurred to look at the effects of poor waste management on weather (Temperature) variability in the vicinity of waste dump sites in Benin City.

\section{Materials and Methods}

Benin city is located on lat $6^{\circ} 20^{\prime}, 660^{\prime \prime} \mathrm{N} \&$ long $5^{\circ} 37^{\prime} 8$ ' $92^{\prime \prime} \mathrm{E}$ (see figure 1). The city is bounded to the north by Uhunmwode LGA, to the south by Ologbo, the east by Orhiomwon LGA and the west by Ovia south west. It is also the capital city of Edo State and had an approximate population of 1.2million in 2006 (NPC, 2006), with a growth rate of 3.3 the population is projected to reach 1.6 milloin by 2017 . Nevertheless, the area also enjoys the tropical type of climate with annual temperature of $29^{\circ} \mathrm{C}$ and a rainfall amount that ranges 


\section{Macrothink}

between $20.4 \mathrm{~mm}$ to $300 \mathrm{~mm}$ (Okudibie, 2014). The population rise, poor waste management practice and the climate have contributed to waste management situation in the city.

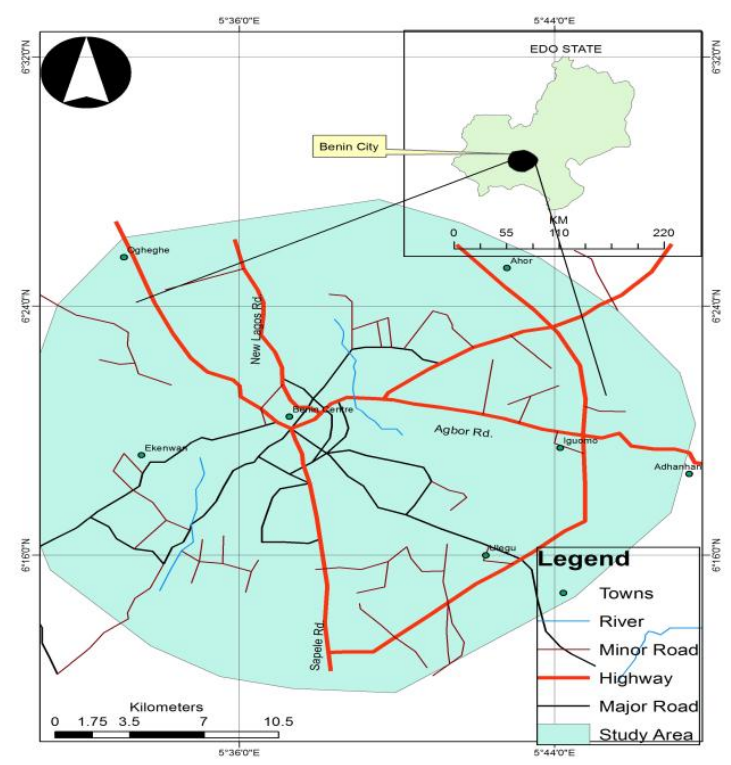

In terms of methods the study adopted the experimental research design. Therefore, the major waste dumps in the city were identified (see fig 2 ) and this formed the population for the study (see table 1).

Table 1. Neighbour hoods in the vicinity of waste dumpsites

\begin{tabular}{|l|l|}
\hline Dump site & Neighbour hoods \\
\hline Ugbowo & Ekosodi, Uselu, Oluku, Okhoro, Edaiken, Isihor \\
\hline Sapele-Road & $\begin{array}{l}\text { Erediawa, Power-Line, Santana-Market, Evbuo-riaria, } \\
\text { PZ-road, Okabere, Evbuo-khun }\end{array}$ \\
\hline Iguomo & Iguomo, Ikhuen, Depot, Okuahe, By-pass, \\
\hline Ekehuan & Iyaro, Ekehuan, Siloko, Staidium-Road, Oba-Market \\
\hline $\begin{array}{l}\text { Aduwawa/ } \\
\text { Ohovbe }\end{array}$ & Aduwawa, Ohovbe, First-Upstairs, Kojo, Urhuora \\
\hline Ugbor & GRA, First ugbor, Second Ugbor, Ogba, Airport-road \\
\hline Upper-mission & $\begin{array}{l}\text { Uteh, Mission road, New Lagos road, Upper-mission, } \\
\text { Ipkoba-slope, new-Benin, MM-way }\end{array}$ \\
\hline
\end{tabular}

To be able to measure the waste volume generated at the various dump sites, the quadrant technique (which involves the separation of dumpsites into quadrants of equal measurements and in this case 1 by 1 meter) was used (see table 2). 


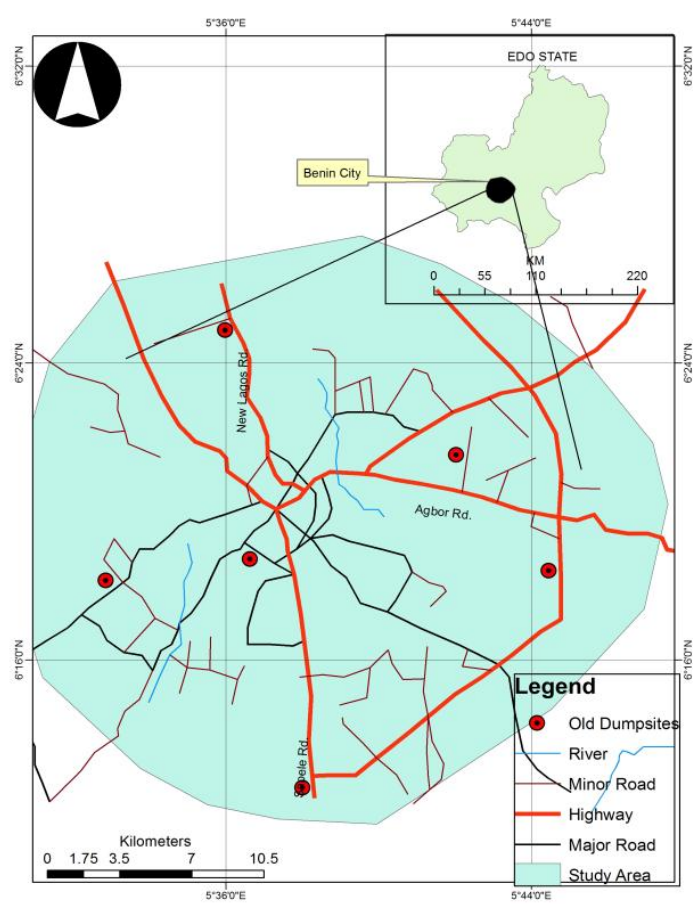

Figure 2. Benin city Showing waste dump-sites

Table 2. Dump sites, sizes and number of quadrants derived in Benin city

\begin{tabular}{|l|l|l|l|l|}
\hline Dump site & Length $(\mathrm{m})$ & Breadth$(\mathrm{M})$ & Area $\left(\mathrm{M}^{2}\right)$ & Derived Quadrants \\
\hline Ugbowo & 54 & 39 & 2196 & 2196 \\
\hline Sapele-Road & 66 & 33.3 & 2197.8 & 2197.8 \\
\hline Iguomo & 91 & 66 & 6006 & 6006 \\
\hline Ekewhan & 45 & 30 & 1350 & 1350 \\
\hline Aduwawa/Ohovbe & 78 & 63 & 4914 & 4914 \\
\hline Ugbor & 24 & 27 & 648 & 648 \\
\hline Upper-mission & 72 & 57 & 4104 & 4104 \\
\hline
\end{tabular}

Thus with the aid of scavengers and a measuring tape, the length and breadth of the dumpsites were determined. After this, the 1 by $1 \mathrm{~m}$ quadrants were super-imposed on the dump sites, hence aiding the scavengers to determine the waste volumes in the dump sites across the city. It was also paramount to have an idea of waste volume generated at the neighbourhoods of waste dumpsites for to see if the waste generated were a reflection of the volume of wastes determined at the waste dumps. This was however determined with the aid of the waste managers that collected waste at the various residents in the area weekly. Furthermore multigas detectors were used to generate information about GHGs such as carbon iv oxide $\left(\mathrm{CO}_{2}\right)$ Methane gas $\left(\mathrm{CH}_{4}\right)$, Nitrogen Oxide $\left(\mathrm{NO}_{2}\right)$, sulphur Oxide $\left(\mathrm{SO}_{2}\right)$, Ammonium gas $\left(\mathrm{NH}_{4}\right)$; at the various dumpsites and at the control point (Upper-sokpan-oba); both in the morning (6am) and at evening $(6 \mathrm{pm})$. This was to help the researcher capture the daytime and night time variation in GHGs emission at the dumpsite and control.

Furthermore, digital thermometers were used to decipher the mean temperature both at dump sites and at distances away from the dumpsites using the distance decay technique. As such, 
temperature was measured at dumpsites, $2.5 \mathrm{~km}$ and $5 \mathrm{~km}$ from the dumpsite hourly for 3 months. In terms of analysis, ANOVA was used to determine the statistical significance in temperature with distance from the dumpsites, while the MLR was used to determine the level of dependence of temperature on the GHGs emission in the area.

\section{Results and Discussion}

Generally in table 3, wastes volume generated are displayed. From the table, upper mission generated the highest amount of waste in the study period with $43211 \mathrm{~kg}$ of waste. Iguomo is the second waste dump with high amount of wastes in the area, with $34105 \mathrm{~kg}$ of waste. The waste dump with the lowest amount of waste in the area is Ugbor $(11261.6 \mathrm{~kg})$. Several factors account for the wastes volumes found at each wastes dump. For example upper mission dump-site is the closest dump-site to New Benin market, which is arguably the largest daily market in the city. Secondly, some waste managers prefer to empty their waste into this dump site for two reasons; a) the community where the waste dump is located is less hostile and so waste managers can bring in wastes from other areas not intended to empty their waste in the dump site; b) secondly, the waste dump site is poorly managed as such individuals can dump their wastes indiscriminately on the dumpsite without any apprehension.

Table 3. Volumes of waste generated within the study period at identified dump-sites

\begin{tabular}{|l|l|}
\hline Waste sites & Volume Generated $(\mathrm{Kg})$ \\
\hline Ugbowo & 13175 \\
\hline Sapele-Road & 27321 \\
\hline Iguomo & 34105 \\
\hline Ekehuan & 23664 \\
\hline Aduwawa/Ohovbe & 18324 \\
\hline Ugbor & 11261.6 \\
\hline Upper-mission & 43211 \\
\hline Total & 171061.6 \\
\hline
\end{tabular}

Surprisingly, Ugbowo which plays host to the University of Benin and the teaching hospital (UBTH) and the consequent attraction of high population (residents), generated the lowest amount of waste $(11261.6 \mathrm{~kg})$ in the study period. This may be due to the activities of scavengers who have a camp at the bypass (by oluku). Therefore the scavengers reduce the waste volumes before they eventually get to the waste dump. This finding is inconsistent with that of Efe et el., (2013) who emphasized that wastes are usually deposited at the nearest dumpsites to generation points. It therefore means that the activities of wastes managers and scavengers may affect the volume of waste in a given waste dump.

Table 4. Waste volume in Neighborhoods within the vicinity of waste-dumps ( Kg)

\begin{tabular}{|c|l|l|c|c|}
\hline S/N & Neigh-Bourhoods & Nature of Neigh-bourhood & Waste Generated & \% \\
\hline 1 & Ekosodi & Residential & 1241 & 1.75 \\
\hline 2 & Uselu & Commercial/residential & 2536 & 3.6 \\
\hline
\end{tabular}




\begin{tabular}{|c|c|c|c|c|}
\hline 3 & Oluku & Residential/commercial & 875 & 1.2 \\
\hline 4 & Okhoro & Residential & 653 & 0.9 \\
\hline 5 & Edaiken & Residential & 457.5 & 0.65 \\
\hline 6 & Isihor & Residential & 234 & 0.3 \\
\hline 7 & Erediawa & Residential & 765.5 & 1.08 \\
\hline 8 & Power-Line & Commercial & 234 & 0.3 \\
\hline 9 & Santana-Market & Commercial & 1573 & 2.2 \\
\hline 10 & Evbuo-riaria & Residential & 1265.6 & 1.79 \\
\hline 11 & PZ-road & Residential & 2342 & 3.3 \\
\hline 12 & Okabere & Residential & 743 & 1.05 \\
\hline 13 & Evbuo-khun & Residential & 453 & 0.6 \\
\hline 14 & Iguomo & Residential & 5433 & 7.7 \\
\hline 15 & Ikhuen & Residential & 458 & 0.7 \\
\hline 16 & Depot & Commercial/residential & 1254 & 1.8 \\
\hline 17 & Okuahe & Residential & 235 & 0.3 \\
\hline 18 & By-pass & Residential & 433 & 0.8 \\
\hline 19 & Iyaro & Commercial/residential & 874 & 1.2 \\
\hline 20 & Oba-Market & Commercial & 2875.8 & 4.1 \\
\hline 21 & Staidium-Road & Residential/commercial & 567 & 0.8 \\
\hline 22 & Siloko & Commercial & 753 & 1.1 \\
\hline 23 & Ekehuan & Residential/commercial & 5476.9 & 7.8 \\
\hline 24 & Aduwawa & Commercial/industrial & 3273.5 & 4.6 \\
\hline 25 & Ohovbe & Residential & 2382 & 3.37 \\
\hline 26 & First-Upstairs & Commercial/residential & 2365.4 & 3.3 \\
\hline 27 & Kojo & Commercial/residential & 453.6 & 0.6 \\
\hline 28 & Urhuora & Residential & 1235.5 & 1.7 \\
\hline 29 & GRA & Residential & 4785.7 & 6.8 \\
\hline 30 & First ugbor & Residential & 2336.5 & 3.3 \\
\hline 31 & Airport-road & Commercial/residential & 867.5 & 1.2 \\
\hline 32 & Second Ugbor & Residential & 345.7 & 0.5 \\
\hline 33 & Ogba & Residential & 238.9 & 0.3 \\
\hline 34 & Uteh & Residential & 2365.7 & 3.4 \\
\hline 35 & Mission road & Commercial & 3765.8 & 5.3 \\
\hline 36 & New Lagos road & Commercial/residential & 3455.7 & 4.9 \\
\hline 37 & Upper-mission & Residential & 3211.5 & 4.6 \\
\hline 38 & Ikpoba-slope & Commercial/residential & 785 & 1.1 \\
\hline 39 & new-Benin & Commercial/residential & 6505.1 & 9.2 \\
\hline 40 & MM-way & Commercial & 545.5 & 0.77 \\
\hline Total & & & 70650.9 & 100 \\
\hline
\end{tabular}

Nevertheless, in table 4, neighbourhoods located near commercial and high residential areas generated more volume of waste than the low income earner neighbourhoods. This is evident in neighbourhoods such as new Benin, with $9.2 \%$ of the total waste volume generated in the 
study period. Whereas Ogba which is a low income earner neighbourhood, generated only $0.3 \%$ of the total waste generated. Adducible reasons for this variation include influence of the markets that scatter around the city, shops located within residential units in the commercial areas that service population interacting with businesses in the area.

Table 5. Average volume of greenhouse gases $(\mu / \mathrm{m} 3)$ emitted and temperature in the vicinity of waste-dumps in Benin

\begin{tabular}{|l|c|c|c|c|c|c|l|}
\hline Land-use & Epoch & $\mathbf{C O}_{\mathbf{2}}$ & $\mathbf{C H}_{\mathbf{4}}$ & $\mathbf{N H}_{\mathbf{4}}$ & $\mathbf{N O}_{\mathbf{2}}$ & $\mathbf{S O}_{\mathbf{2}}$ & Temp. $\left({ }^{\mathbf{0}} \mathbf{C}\right)$ \\
\hline Ekewhuan & a.m. & 24.19 & 20.85 & 19.25 & 5.85 & 6.05 & \\
\hline & p.m. & 20.64 & 18.02 & 19.06 & 3.96 & 4.69 & $\mathbf{3 1 . 5}$ \\
\hline Ugbowo & a.m. & 23.69 & 19.80 & 19.65 & 5.62 & 5.12 & \\
\hline & p.m. & 22.51 & 18.92 & 20.01 & 4.86 & 4.89 & $\mathbf{3 1}$ \\
\hline Iguomo & a.m. & 21.69 & 20.10 & 17.74 & 5.70 & 5.82 & \\
\hline & p.m. & 21.04 & 19.02 & 18.05 & 4.98 & 5.09 & $\mathbf{2 9 . 5}$ \\
\hline Medium & a.m. & 22.19 & 19.89 & 19.92 & 4.57 & 4.63 & \\
\hline Density residential & p.m. & 21.54 & 19.12 & 20.06 & 4.01 & 4.01 & $\mathbf{2 9 . 8}$ \\
\hline Upper & a.m. & 24.91 & 20.17 & 20.94 & 5.34 & 6.08 & $\mathbf{3 1 . 5}$ \\
\hline mission & p.m. & 23.82 & 19.31 & 21.06 & 5.08 & 5.89 & \\
\hline Aduwawa/ & a.m. & 21.36 & 19.05 & 18.69 & 4.92 & 5.22 & \\
\hline Ohovbe & p.m. & 20.94 & 18.85 & 19.25 & 4.58 & 4.99 & $\mathbf{3 0 . 5}$ \\
\hline Ugbor & Am & 21.36 & 19.05 & 18.69 & 4.92 & 5.22 & $\mathbf{3 0 . 5}$ \\
\hline & Pm & 20.94 & 18.85 & 19.25 & 4.58 & 4.99 & \\
\hline Control & a.m. & 14.02 & 12.72 & 11.64 & 3.03 & 4.35 & \\
\hline & p.m. & 14.75 & 13.28 & 12.08 & 2.89 & 3.89 & $\mathbf{2 7 . 8}$ \\
\hline
\end{tabular}

In table 5, the average amounts of GHGs as well as the temperature reached are shown. In the table temperature characteristics reflect the volume of GHGs attained. Secondly, GHGs emissions in the morning are higher than that, emitted in the evening, the reason being that, waste incineration at dumpsite takes place at nights also; atmospheric conditions are more stable at nights than in the daytime. Due to the fact that, winds and other anthropogenic activities displace GHGs from emission sources to other areas (Edokpa, 2017).

Table 6. Ambient temperatures at the waste dumps and distance away from dump-sites in Benin

\begin{tabular}{|l|l|l|l|}
\hline Land use & Temp. at D-site $\left({ }^{\mathbf{0}} \mathbf{C}\right)$ & Temp. $\left({ }^{\mathbf{0}} \mathbf{C}\right) \mathbf{2 . 5} \mathbf{k m}$ & Temp. $\left({ }^{\mathbf{0}} \mathbf{C}\right) \mathbf{5 k m}$ \\
\hline Ekewhuan & 31.5 & 31 & 30 \\
\hline Ugbowo & 31 & 30.5 & 30.5 \\
\hline Sapale-road & 29.8 & 29.5 & 29 \\
\hline Iguomo & 29.5 & 29.5 & 29 \\
\hline Upper mission & 31.5 & 31 & 31 \\
\hline Aduwawa/Ohovbe & 30.5 & 30 & 30 \\
\hline Ugbor & $\mathbf{3 0 . 5}$ & $\mathbf{3 0 . 1}$ & $\mathbf{2 9 . 7}$ \\
\hline Control & $\mathbf{2 7 . 8}$ & $\mathbf{2 7 . 8}$ & $\mathbf{2 7 . 8}$ \\
\hline
\end{tabular}




\section{Ml Macrothink}

Environmental Management and Sustainable Development

ISSN 2164-7682

2018, Vol. 7, No. 4

However, the high concentration of GHGs at dumpsites is attributed to fermentation of wastes materials, decomposition of organic material within the waste constituents, and waste incineration at dumpsites. This finding disagrees with the findings of Efe et al.,(2013); Yusuf \&Oyewunmi, (2008) \& O'Neil et al (2001), who attributed volume of GHGs at waste dumps to anthropogenic activities, population growth and industrial processes. Nevertheless, the emitted gases have effect on temperature variability in the area. This assertion is glaring in table 6, where temperature reduces as one moves away from the dumpsites. For example, in Ekewhuan, at $5 \mathrm{~km}$ from the dumpsite a temperature gain of $1.5^{\circ} \mathrm{C}$ is recorded. At sapele road $0.8^{0} \mathrm{C}$ is recorded at $5 \mathrm{~km}$ from the dumpsite. The same can be said of other dumpsites in the area, thereby revealing that, the GHGs are responsible for the temperature variation in the vicinity of waste dumps as compared with distance away from dumpsites (Sridhar, 2006).

Table 7. Temperature variation with distance from dump site

\begin{tabular}{|c|c|c|c|c|}
\hline \multicolumn{5}{|c|}{ ANOVA } \\
\hline \multicolumn{5}{|l|}{ Temperature } \\
\hline & Sum of Squares & Df & Mean Square & $\mathrm{F}$ \\
\hline Between Groups & 1396.922 & 3 & 798.974 & 26.307 \\
\hline Within Groups & 16005.888 & 87 & 43.380 & \\
\hline Total & 17402.81 & 90 & & \\
\hline
\end{tabular}

Table 8. Duncan analysis of temperature variation with distance from dump site

\begin{tabular}{|l|c|c|c|c|}
\hline \multicolumn{5}{|l|}{ Temperature variation with distance } \\
\hline Duncan $^{\mathrm{a}}$ & \multirow{5}{|l|}{$\mathrm{N}$} & \multicolumn{3}{|c|}{ Subset for alpha $=0.05$} \\
\cline { 3 - 5 } & & 1 & 2 & 3 \\
\hline 5 Identifiers & 90 & 29.0811 & & \\
\hline $2.5 \mathrm{~km}$ & 90 & & 30.2501 & \\
\hline Vicinity of D site & 90 & & & 30.6333 \\
\hline Sig. & & 1.000 & 1.000 & 1.000 \\
\hline Means for groups in homogeneous subsets are displayed. \\
\hline
\end{tabular}

a. Uses Harmonic Mean Sample Size $=10950.000$.

This assertion is found to be statistically, significant at $\mathrm{p}<0.05(\mathrm{~F}, 26.3 ; \mathrm{p}, 0.00)$ in table 7 . This thus reveals that the variation in temperature at distances from dumpsite is statistically significant. However, table 8 showed that temperature is lower at $5 \mathrm{~km}\left(29.1^{0} \mathrm{C}\right)$, higher at $2.5 \mathrm{~km}\left(30.3^{\circ} \mathrm{C}\right)$ and highest at dumpsite $\left(30.6^{\circ} \mathrm{C}\right)$. This finding is in congruence with the distance decay concept and consistent with the findings of (Ozabor \& Obaro, 2016)

Table 9. Regressions model summary for the effect of GHGs on temperature

\begin{tabular}{|l|l|l|l|l|l|l|l|l|l|}
\hline Model & R & R Square & $\begin{array}{l}\text { Adjusted R } \\
\text { Square }\end{array}$ & $\begin{array}{l}\text { Std. Error } \\
\text { of the Estimate }\end{array}$ & \multicolumn{3}{|l|}{ Change Statistics } \\
\cline { 5 - 9 } & & & R Square Change & F Change & df1 & df2 & Sig. F Change \\
\hline 1 & $\mathbf{. 9 2 1}$ & $\mathbf{. 8 5 0}$ & $\mathbf{. 7 2 8}$ & $\mathbf{. 6 0 4 7 4}$ & $\mathbf{. 8 5 0}$ & $\mathbf{1 6 . 7 3 9}$ & $\mathbf{5}$ & $\mathbf{4}$ & $\mathbf{. 0 0 7}$ \\
\hline
\end{tabular}




\section{I Macrothink}

The regressions analysis further confirms that temperature behaviour at dumpsite significantly depends, on GHGs at $\mathrm{p}<0.05$ (see table 9). Also worthy of note in table 9 is that $85 \%$ of temperature characteristics in the dump sites can be explained by GHGs emitted at the dump sites, leaving the other $15 \%$ to atmospheric interactions, anthropogenic activities etc.

\section{Recommendations and Conclusion}

This research has shown empirically, that there is temperature variability occasioned by waste dumpsites in the vicinity of waste dumps in Benin City. Poor waste management practice and emission of GHGs from the waste dumps have been identified as factors responsible for the temperature characteristics in the vicinity of waste dumps in the City. Furthermore, the use to which land is put also had some effects on waste volume generated as the commercial and residential land uses recorded the highest volumes of wastes. The level of GHGs emission at dumpsite and its influence on temperature is disturbing. Therefore, a continuous practice of the current approach to waste management would not only pose severe threat to weather of places near waste dumps, but will also snowball into a city- wide or regional problem of climate.

It is therefore important to identify sites suitable for waste treatment plants as suggested in figure 3. This will exterminate overstay and incineration of waste at dumpsite thereby reducing emissions of GHGs.

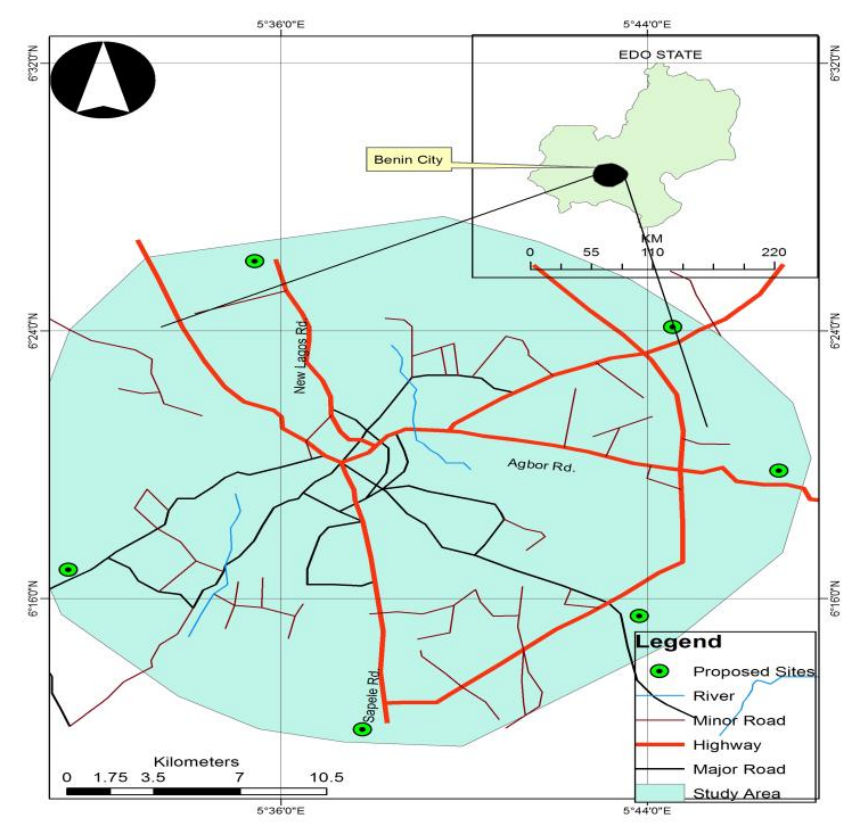

Figure 3. Benin City showing proposed waste treatment plants

Furthermore, a city-wide re-orientation of locals by both the government, cooperate and non-governmental organisations on the need to sort waste at source is paramount. This will contrive the processes of waste recycle and reuse; and introduce a process of making a living 
through waste thereby reducing GHGs emissions (Ozabor \& Obisesan, 2017). Finally, the state government should establish a waste management framework; which will include waste policing, licensing and training abundance of \& affordable waste management vendors, and a periodic orientation of locals on the need to align with the waste management plan of the state. If these steps are followed practically, wastes effects on weather variability in Benin City will be minimized.

\section{References}

Aboyade, A. (2004). The Potential for Climate Change Mitigation in Nigeria Solid Waste Disposal Sector: A Case Study of Lagos. An Unpublished MSc Dissertation, Department of Environmental Strategy, Lund University.

Agbola, T., \& Jinadu, A. M. (2006). Community Reactions and Environmental Impact Assessment of a Landfill Site in an Indigenous African City. In: T. Agbola, Ed., Environmental Planning and Management: Concepts and application to Nigeria. Ibadan Constellation Books, Ibadan, 2006, pp. 114-145.

Ajie, U. E., \& Dienye, A. (2014). Spatial Data Analysis of Solid Waste Management System in Port Harcourt Metropolis after 100 years of its Existence. FIG Congress 2014 Engaging the Challenges - Enhancing the Relevance. Kuala Lumpur, Malaysia 16-21 June 2014

Babayemi, J. O., \& Dauda, K. T. (2009). Evaluation of Solid Waste Generation, Categories and Disposal Options in Developing Countries: a case Study of Nigeria. Journal of Applied Science Environmental Management, 13(3), 83-88.

Bogner, J. M., Ahmed, A., Diaz., C., Faaij, A., Gas, O., Hashimoto, S., Mareckova, K., Pipatti., R., \& Zhang, T. (2007). Waste Management. In: B. Metz, O. R. Davidson, P. R. Boseh, R. Dave and L. A. Meyer, Eds., Climate Change 2007: Mitigation Contribution of Working, 2007.

Edokpa, O. D. (2017). Atmospheric stability conditions in the lower troposphere in selected cities of Nigeria. A PhD thesis submitted to the department of Geography and Environmental Management, University of Port-Harcourt, Nigeria

Efe, S. I. (2002). Urban Warming in Nigeria Cities: The Case of Warri Metropolis. African Journal of Environmental Studies, 3(1-2), 160-168.

Efe., S. I., Cheke., L. A., \& Ojoh., C. O. (2013). Effects of Solid Waste on Urban Warming in Warri Metropolis, Nigeria. Journal of Atmospheric and Climate Sciences, 3, 6-12.

https://doi.org/10.4236/acs.2013.34A002

O’Neill, B., Landis, C. F., Kellar, M., \& Lutz, W. (2001). Population and Climate Change. Cambridge University Press, London.

Ogu, V. I. (2000). Private Sector Participation and Municipal Waste Management in Benin City, Nigeria. Environment and Urbanization, 12(2), 103-117.

https://doi.org/10.1177/095624780001200209 


\section{Macrothink}

Environmental Management and Sustainable Development

ISSN 2164-7682

2018, Vol. 7, No. 4

Ozabor, F., \& Obaro, H. N. (2016). Health effects of poor waste management in Nigeria: a case study of Abraka in Delta State. Int. J. Environment and Waste Management, 18(3), 195-204. https://doi.org/10.1504/IJEWM.2016.080790

Ozabor \& Obisesan (2017). the role of government and private partnership in eradicating street waste dumps in Port Harcourt. Paper presented at the $58^{\text {th }}$ Association of Nigerian Geographers Conference, held in Nasarawa State, Nigeria.

Wokekoro, E., \& Inyang, M. P. (2007). Waste Disposal in Low-Income Neighbourhoods and Its Impact on Health: The Case of Port Harcourt, Nigeria. International Conference "Waste Management, Environmental Geotechnology and Global Sustainable Development (ICWMEGGSD'07 - GzO'07)” Ljubljana, SLOVENIA, August 28-30.

Sánchez-Rodríguez, R., Seto, K., Simon, D., Solecki, W., Kraas., F., \& Laumann, G. (2005). Science Plan: Urbanization and Global Environmental Change IHDP Report 15 International Huma Dimensions Programme on Global Environmental Change, Bonn," 2005. http://www.ihdp.org http://www.ugec.org

Sridhar, M. K. C. (2006). From Urban Wastes to Sustainable Waste Management in Nigeria: A Case Study. In: F. A. Matt, A. Ivbijaro, F. Akintola and R. U. Okechukwu, Eds., Sustainable Environmental Management in Nigeria, Chapter 20, Mattivi Productions, Ibadan, 2006, pp. 337- 353.

Stewart, I. D. (2001). Influence of Meteorological Conditions on the Intensity and Form of the Urban Heat Island Effect in Regina. Canadian Geographer-Geographe Canadien, 44(3), 71-285. http://dx.doi.org/10.1111/j.15410064.2000.tb00709.x

Yusuf, R. O., \& Oyewunmi, M. O. (2008). Qualitative Assessment of Methane Generation Potential from Municipal Solid Wastes: A Case Study. Environmental Research Journal, 2(4), 138-144.

\section{Copyright Disclaimer}

Copyright for this article is retained by the author(s), with first publication rights granted to the journal.

This is an open-access article distributed under the terms and conditions of the Creative Commons Attribution license (http://creativecommons.org/licenses/by/3.0/). 